pulsed macrophages by using the macrophages pulsed with either gp86 preparation to stimulate CTLs against an irrelevant tumor None of the pulsed macrophages could stmulate the tumor specific CTLS

19 For in vitro reconstitution of gp96 peptıde com plexes gp96 derived from normal Iiver $(50 \mu \mathrm{g})$ and 125 labeled peptides $(5 \mu \mathrm{g})$ were incubated at $50^{\circ} \mathrm{C}$ for $10 \mathrm{~min}$ followed by room temperature for 30 min Free peptides were removed by extensive washing with Microcon 50 (Amicon), such that no free peptides were detected on SDS-polyacryl amide gel electrophoresis of the complexes ( $Z \mathrm{~L}$ $R$ Suto $P K$ Srivastava, In preparation)

20 The sequence of VSV20 is Ser Leu Ser Asp Leu Arg Gly Tyr Val Tyr Gin Gly-Leu Lys Ser Gly Asn Val Ser Cys The sequence of the negative contro VSV peptide A is Lys Arg GIn lle Tyr Thr Asp Leu Glu Met Asn Arg Leu Gly Lys

$21 \mathrm{C} 57 \mathrm{BL} / 6$ mice $\left(H 2^{b}\right.$ haplotype) were subcutane ously injected twice at a 7 day interval with gp96 (10 $\mu \mathrm{g}$ in phosphate buffered saline) denved from unin fected or VSV infected Meth A cells or EL 4 cells Seven days after the second vaccination spleens were removed and spleen celis $\left(8 \times 10^{6}\right.$ cells per well) were cocultured in mixed lymphocyte tumor culture (MLTC) with irradiated N1 cells $\left(14 \times 10^{5}\right.$ cells per well) in 24 well plates On day 7 each well was harvested Serially diluted culture cells were tested against $\mathrm{N} 1$ cells or EL 4 cells for cytotoxicity in a ${ }^{5} \mathrm{C}$ r release assay

22 Supported by $\mathrm{NIH}$ grant CA44786 RS is a post doctoral fellow of the Cancer Research Institute New York

28 June 1995 accepted 22 August 1995

\title{
Human H-Y: A Male-Specific Histocompatibility Antigen Derived from the SMCY Protein
}

\author{
Wei Wang, ${ }^{*}$ Leslie R. Meadows, ${ }^{*}$ Joke M. M. den Haan, ${ }^{*}$ \\ Nicholas E. Sherman, ${ }^{*}$ Ye Chen, Els Blokland, \\ Jeffrey Shabanowitz, Alexander I. Agulnik, \\ Ronald C. Hendrickson, Colin E. Bishop, Donald F. Hunt, \\ Els Goulmy, $\dagger$ Victor H. Engelhard
}

$\mathrm{H}-\mathrm{Y}$ is a transplantation antigen that can lead to rejection of male organ and bone marrow grafts by female recipients, even if the donor and recipient match at the major histocompatibility locus of humans, the HLA (human leukocyte antigen) locus. However, the origin and function of $\mathrm{H}-\mathrm{Y}$ antigens has eluded researchers for 40 years. One human $\mathrm{H}-\mathrm{Y}$ antıgen presented by HLA-B7 was identified as an 11-residue peptide derived from $S M C Y$, an evolutionarly conserved protein encoded on the $Y$ chromosome. The protein from the homologous gene on the $X$ chromosome, SMCX, differs by two amino acid residues in the same region. The identificatıon of $\mathrm{H}-\mathrm{Y}$ may aid in transplantation prognosis, prenatal diagnosis, and fertilization strategies.

Histocompatibility antigens that can induce transplant rejection include the class I and class II molecules of the major histocompatibility complex (MHC), as well as a large number of so-called minor histocompatibility (H) antigens In mice, the use of inbred strains has shown that minor $\mathrm{H}$ antigens are encoded by almost 50 different allelically polymorphic loci scattered throughout the genome (1) Humans also have minor $\mathrm{H}$ ant1gens although therr overall number and com- plexity remains uncertain Both species have the male specific antigen $\mathrm{H}-\mathrm{Y}(2,3) \mathrm{H}-\mathrm{Y}$ was inutially identified through the observation that within an inbred mouse strain, most of the male-ro-female skin grafts were rejected, whereas transplants in other sex combinations nearly always succeeded (2) In humans, sex mismatch is a significant risk factor associated with rejection or the development of graftversus-host disease in bone marrow transplant recipients $(3-6)$ The $H-Y$ antigen is ex- pressed in most different human tissues $(4,7)$, and $H-Y$ specific immune responses occur during the transplantation of other organs, blood transfusion, and pregnancy (8)

As with other minor $H$ antigens, the recognition of $\mathrm{H}-\mathrm{Y}$ by $\mathrm{T}$ lymphocytes is MHC-restricted $(3,9)$, and some H-Y antigens are peptides derived from cellular proteins that are presented on the cell surface in association with MHC class I molecules (10) We have developed a technique for the identification of individual peptides that are bound to MHC molecules and recognized as antigens by $T$ cells $B y$ combining microcapillary liquid chromatography-electrospray ionization mass spectrometry with $T$ cell epitope reconstitution assays $(11-13)$ we now report the identif $1-$ cation of a peptide antigen recognized by a human cytotoxic $\mathrm{T}$ lymphocyte (CTL) clone that is $\mathrm{H}-\mathrm{Y}$-specific and restricted by the class I MHC molecule HLA-B7

To isolate endogenously processed $\mathrm{H}-\mathrm{Y}$ peptides, HLA-B7 molecules were purified by affinity chromatography from the H-Y positive, B lymphoblastord cell line JY (14) The associated peptides were extracted in acid and separated from high molecular weight material by ultrafiltration (15) and subsequently fractionated by reverse-phase high-pressure liquid chromatography (HPLC) (11) Samples of each fraction were incubated with HLA-B7 ${ }^{+}, \mathrm{H}-\mathrm{Y}^{-}$T2-B7 target cells to assay for reconstitution of the epitope recognized by

Fig. 1. Reconstitution of the H-Y epitope with HPLC-fractionated peptides extracted from HLA-B7 molecules (A) HLA-B7-molecules were immunoaffinity purfied form $2 \times 10^{10} \mathrm{H} Y^{+} J Y$ celis Peptides were eluted from B7 molecules with $10 \%$ acetic acid, $\mathrm{pH} 21$, filtered through a 5-kD cut-off filter and fractionated on a $\mathrm{C} 18$ reverse phase column Buffer $\mathrm{A}$ was $01 \%$ heptafluorobutyric acid (HFBA) and buffer $B$ was $01 \%$ HFBA in acetonitrile The gradient consisted of $100 \%$ buffer $A$ (C to $20 \mathrm{~min}$ ), 0 to $12 \%$ buffer $B$ ( 20 to $25 \mathrm{~min}$ ), and 12 to $50 \%$ buffer $B(25$ to $80 \mathrm{~min})$ at a flow rate of $200 \mu \mathrm{l} / \mathrm{min}$ Sixty fractions of $200 \mu \mathrm{leach}$ were collected from 20 to $80 \mathrm{~min}$ (B) Fractions 28 and 29 from the separation

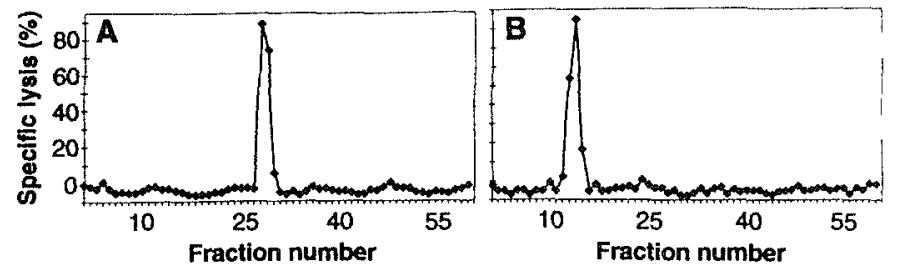
shown in (A) were rechromatoararhnr! sith he Salie acetonitrile gradient, but using trifluoroacetic acid (TFA) instead of HFBA as the organic modifier For both panels, $3 \%$ of each peptide fraction was incubated with 1000 ${ }^{51} \mathrm{Cr}$-labeled T2-B7 cells at room temperature for 2 hours CTLs were then added at an effector to target ratio of 10 to 1 and further incubated at $37^{\circ} \mathrm{C}$ for 4 hours Background lysis of T2-B7 by the CTL in the absence of any peptides was $-3 \%$ in $(A)$ and $-4 \%$ in $(B)$, positive control lysis of $J Y$ was $75 \%$ in (A) and $74 \%$ in (B) (C) Determination of candidate $\mathrm{H}-Y$ peptıde by mass spectrometry combıned with ${ }^{51} \mathrm{Cr}$ release assay $\mathrm{HPLC}$ fraction 14 from the separation in $\mathrm{Fig} 1 \mathrm{~B}$ was chromatographed with an on-Ine microcapillary column effluent splitter as previously described $(11,13)$ One-fifth of the effluent was deposited into $100 \mu /$ of culture media in microtiter plate wells for analysis with CTLs The remaining four-fifths of the matenal were directed into the electrospray Ionization source, and mass spectra of the peptides deposited in each well were recorded on a triple-quadruple mass spectrometer (Finnigan-MAT, San Jose, California) (\$) H epitope reconstitution activity measured as percent specific lysis (1), abundance of peptide 1171 measured as ion current at $\mathrm{m} / \mathrm{z} 391$

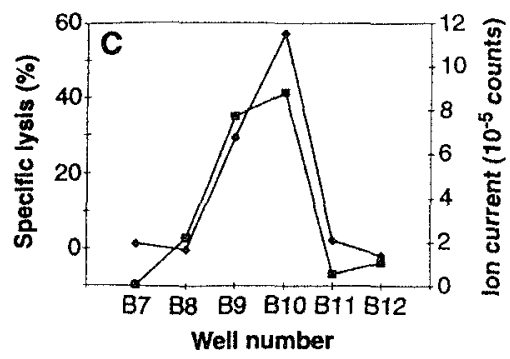


ig. 2. The CAD mass spectrum of peptide 1171 after conversion the $R$ resi jue to omithine Material rom second dimension IPLC fraction 14 shown in ig 18 was treated with ${ }^{7} 0 \%$ hydrazine hydrate for 1 lour The CAD mass spec num was recorded on the $M+2 H)^{+2}$ ion at $m / z 566$

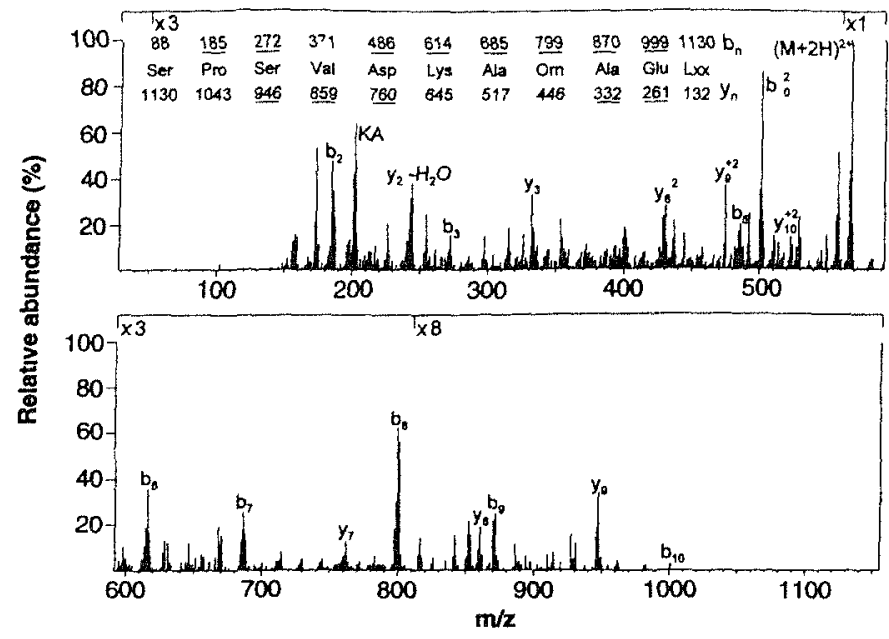

an HLA-B7 restricted, H-Y-specific CTL lone, 5W4 (16) A single peak of reconst1turing activity was observed (Fig 1A), which was rechromatographed in a different organic modifter Although a single active peak of reconstituting activity was also observed from this separation ( $\left.F_{1 g} 1 B\right)$, it still contaned more than 100 distinct peptide species, as assessed by electrospray ionization tandem mass spectrometry

To identify the active H-Y peptide in this mixture, we applied each active fraction separately to a microcapillary HPLC column and split the effluent after the separation (11) Four-fifths of the effluent was directed into the mass spectrometer for analysis, while one-fifth was simultaneously directed into a 96-well microtiter plate for a subsequent epitope reconstitution assay The amount of the $\mathrm{H}-\mathrm{Y}$ sensitizing activity in each well was correlated to signals observed in the mass spectrum and therefore to the abundance of different peptide species By comparing the profile of $\mathrm{H}-\mathrm{Y}$ activIty and the ion abundance data (Fig 1C), we identufied an $(\mathrm{M}+3 \mathrm{H})^{+3}$ ion at a massto-charge ratio $(\mathrm{m} / \mathrm{z})$ of 391 (neutral molecular mass $=1171$ ), whose abundance correlated with the amount of $\mathrm{H}-\mathrm{Y}$ epitope reconstituting activity A peptide with an

W Wang $Y$ Chen $V H$ Engelhard Department of $M I$ crobiology and Beime Carter Center for Immunology Re search Universty of Virginia Charlottesville, VA 22908 USA

$L R$ Meadows N E Sherman I Shabanowitz R C Hendnckson Department of Chemistry Unversity of Vir ginia Charlottesville VA 22901 USA

I M M den Haan E Blokland E Goulmy Department of Immunohaematology and Blood Bank Leiden Univer sity Hospital Netherlands

A I Agulnik Promega Corporation Madison W1 53711 USA

C E Bishop Departments of Obstetrics and Gynecology and Human and Molecular Genetics Baylor College of Medicine Houston TX 77030 USA

$D F$ Hunt Departments of Chemistry and Pathology University of Virginia Charlottesville VA 22903 USA

*The first four authors contributed equally to this work and their order should be considered arbitrary

tTo whom correspondence should be addressed

identıcal mass and collisıon-actıvated dissociation (CAD) spectrum was also present in HLA-B7-associated peptides extracted from a second $\mathrm{H}_{-} \mathrm{Y}^{+} \mathrm{B}$ lymphoblastord line, $\mathrm{DM}$, but absent from a spontaneous $\mathrm{H}_{-} \mathrm{Y}^{-}$ loss variant of this cell, DM(-) (17)

Assignment of a complete amino acid sequence to peptide 1171 from the $\mathrm{CAD}$ mass spectrum recorded at the $20 \mathrm{fmol}$ level proved difficult due to the absence of high mass fragment ions containing the amine terminus (b-type 1ons) A series of single, doubly charged, or both fragment tons that contaned the $\mathrm{COOH}$-terminus (y-type ions) identified the $\mathrm{COOH}$-terminal residue as either $L$ or $I$ and the first six amino acids as SPSVDK (18) The difference in molecular mass between this partial sequence and that of the full length peptide suggested the presence of four additional residues, for a total length of 11 Because the candidate peptide existed exclusively in the gas phase as an $(\mathrm{M}+3 \mathrm{H})^{+3}$ ton, and underwent mass

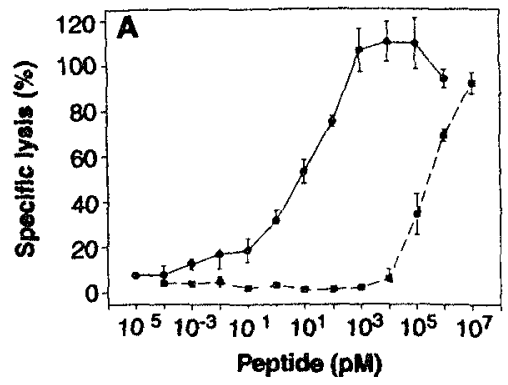
peptides was confirmed by mass spectrometry

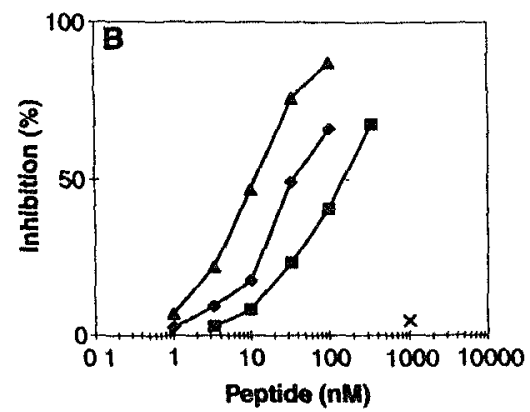

Fig. 3. Reconstitution of the H-Y epitope with synthetic peptides (A) Cytolytic assays ${ }^{51} \mathrm{Cr}$ release was assayed at an effector to target ratio of 10 to 1 on T2-B7 cells that had been incubated with the indicated concentration of SMCY peptide SPSVDKARAEL (1), or SMCX peptide SPAVDKAQAEL (B) (B) Binding of synthetic peptides to purfied HLA B7 HPLC-purfied test peptides were assayed for the ability to inhibit the binding of the iodinated endogenous B7 peptides APRYTVLLL to purified HLA B7 as de scnbed (28) - SMCY peptide SPSVDKARAEL S. SMCX peptide SPAVDKAQAEL, A, APRTLVLLL an endogenous peptide bound to HLA-B7, and $\times$ LLDVPTAAV, an endogenous peptide bound to HLA A2 1 as the negative control Synthetic peptides were purfied to homogeneity by reverse phase-HPLC on a Vydac $\mathrm{C} 4$ column Punty was established on an analytical RP column and the quantity of edch peptide was confirmed by comparing the area of the peak with that of a standard peptide The identity of the

shifts of 42 and $84 \mathrm{Da}$ on conversion to the corresponding methyl ester and acetylated ing residues were assigned as $R$ and either $D$ or E Only two combinations of four residues (AREA and GRDV) meet the above criteria and satisfy the missing mass of $427 \mathrm{Da}$ The CAD spectra recorded on synthetic peptides suggested that $R$ could not be located at etther position 7 or 10 Data bases were with these characteristics, and a sequence consistent at mine of 11 positions was found in residues 963 to 973 of the protein encoded by a gene called XE169 or SMCX (19), which is located on the $X$ chromosome $A$ homolog of SMCX, called SMCY, ts located on the Y chromosome (20) This protein (21) contains a sequence (residues 950 to tions and has the expected mass of $1171 \mathrm{Da}$ A CAD mass spectrum recorded on the nat urally processed material after conversion of the $\mathrm{R}$ residue to ornithine confirmed that its sequence was identical to that found in the MCY protein ( $F_{1 g} 2$ )

the 11 residue SMCY sequence (SPSVDKARAEL) sensitized T2-B7 cells for recogni tion by the H Y specific CTL clone Half maximal lysis was achieved at a peptide concentration of $10 \mathrm{pM}$ (Fig 3A) The corresponding peptide from the sequence of substitutions of A for $S$ at position 3 and $Q$ for $R$ at position 8 Although this peptide also was able to sensitize T2-B7 cells for cognition, comparable killing was only eved with 10,000 times the peptide SMCY peptide the concentration of the of an iodinated standard peptide to purified 
HLA-B7 by $50 \%\left(\mathrm{IC}_{50}\right)$ was $34 \mathrm{nM}$, whereas the $\mathrm{IC}_{50}$ for the SMCX peptide was 140 $\mathrm{nM}$ (Fig. 3B). Thus, the significant difference in the ability of the SMCY and SMCX peptides to sensitize targets for $T$ cell recognition is almost entirely due to the fine specificity of the $T$ cell receptor, rather than the differences in MHC binding affinities. The SMCX peptide was also present in naturally processed peptide extracts of HLA-B7, although its abundance was only $25 \%$ of the SMCY peptide abundance (17). Therefore the peptide epitope representing the HLA-B7-restricted H-Y antigen is derived from the protein encoded by SMCY

The location of the SMCY gene and the control of its expression fit well with those expected of the H-Y antigen based on previous work. Expression of SMCY has been detected in all male tissues tested, as has H-Y $(4,7,19)$ Deletion mapping in humans has placed the HY locus in a portion of interval 6 on the long arm of the human $Y$ chromosome (22), and SMCY maps to this same interval (20) Our work also establishes that the H-Y structural gene is encoded on the $Y$ chromosome, rather than being an autosomal gene controlled by $\mathrm{Y}$. The SMCY and SMCX proteins are $85 \%$ identical, and the SMCX gene is expressed from both the active and the inactive $X$ chromosomes in both mice and humans $(19,23)$. Therefore, self-tolerance to SMCX will limit the number of SMCY peptides that could give rise to H-Y epitopes in association with different MHC molecules. On the other hand, SMCY contans almost 1500 residues, and the over 200 amino acid sequence differences between it and SMCX are scattered relatively uniformly throughout its length. Thus, a large number of distınct SMCY-specific peptides could be generated as H-Y epitopes. Whether the H-Y eptope peptides presented by other MHC molecules are also from SMCY is unknown, because genetic mapping of the mouse $Y$ chromosome has suggested between two and five distinct loct encoding $\mathrm{H}-\mathrm{Y}$ antıgens (24). However, a murine $\mathrm{H}-\mathrm{Y}$ epitope restricted by $\mathrm{H}-2 \mathrm{~K}^{\mathrm{k}}$ has also been shown to be derived from the murne Smcy protein (25). The demonstration that two H-Y epitopes from either mouse or human are derived from the same protein makes SMCY the prime target in searchıng other $\mathrm{H}-\mathrm{Y}$ epitopes.

The iderticicition of the protem that gives rise to an $\mathrm{H}-\mathrm{Y}$ antigen culminates 40 years of uncertainty regarding its origin and many attempts to identify it. The $77 \%$ DNA sequence identity between SMCY and SMCX provides a likely explanation for past farlures to identify $\mathrm{H}-\mathrm{Y}$-encoding genes by subtractive hybridization. Both proteins share significant sequence homology to retinoblastoma binding protein 2 , which has been suggested to be a transcrip- tion factor (26). If SMCY functions as such, its presumed intracellular location would be inconsistent with detection by male-specifIc antibodies that have been shown to recognize cell surface structures (27) Although the function of SMCY, as well as the homologous SMCX, remains unclear, this and other H-Y specific peptides are candidates for immunomodulatory approaches in bone marrow transplantation, genetic probes to be used for prenatal diagnosis in sex-linked congenital abnormallties, and investıgating minumal residual disease and chimerism.

\section{REFERENCES AND NOTES}

1 B Loveland andE Simpson Immunol Today 7223 (1986)

2 E J Elchwald and C R Silmser Transplant Bull 2 148 (1955) R E Bllingham and $W K$ Sivers $J$ Immund 8514 (1960)

3 E Goulmy A Termitelen, B A Bradley $J \mathrm{~J}$ van Rood Lancet il 1206 (1976), E Goulmy A Termı jtelen B A Bradiey $J J$ van Rood, Nature 266, 544 (1977)

4 P J Voogt et al Lancet 335131 (1990)

5 Advisory Committee of the International Bone Marrow Transplant Registry, Bone Marrow Transplant 4, $221(1989)$

6 M M Bortin, Transplant Proc 19, 2655 (1987)

$7 \mathrm{M}$ de Bueger A Bakker J J van Rood, $F$ van der Woude, E Goulmy, J Immunol 149, 1788 (1992) D van der Harst et al Blood 83, 1060 (1994)

$8 \mathrm{E}$ Goulmy in Transplantation Reviews Vol 2, P J Morns and N C Tiney, Eds (Saunders, Philadel phia, 1988), p 29

9 R D Gordon, E Simpson, L E Samelson, J Exp Med 1421108 (1975)

$10 \mathrm{O}$ Rotzschke, $\mathrm{K}$ Falk $\mathrm{H} J$ Wallny $S$ Faath, $\mathrm{H} G$
Rammensee, Scrence 249283 (1990)

11 A L Coxet al, tord 264, 716 (1994)

12 R A Hendersonet al Proc Natl Acad Sct USA 90, 10275 (1993)

13 J M M den Haan et al, Science 2681476 (1995)

$14 \mathrm{M} J$ Tumer et al J Biol Chem 250, $4512(1975)$ $P$ Parham B N Alpert, H T Orr $J \mathrm{~L}$ Strominger ibid 252, 7555 (1977)

15 D F Hunt et al, Scrence 255, 1261 (1992) E L Huczko et al , J Immunol 151, 2572 (1993)

16 E Goulmy, J D Hamilon, B A Bradley J Exp Med 149, 545 (1979)

17 L R Meadows, W Wang N E Sherman I M M den Haan, unpubished results

18 Single-letter abbreviations for the amino acid resi dues are A, Ala, C, Cys, D Asp E Glu $F$ Phe $G$ Gly, H, His, I lle K, Lys, L, Leu M, Met $N$ Asn $P$ Pro Q. Gin, R, Arg, S Ser, T Thr $V$ Val $W$ Trp and $\mathrm{Y}, \mathrm{Tyr}$

$19 \mathrm{~J}$ Wu et al, Human Mol Genet 3 153 (1994) A Aguinik et al, ibid p 879

20 A I Agulnik $M J$ Mitchell $J L$ Lerner D $R$ Woods, C E Bishop, ibid p 873

21 A I Agulnik and $C E$ Bishop, unpublished results 22 M A Cantrell et al Genomics 131255 (1992)

$23 \mathrm{~J}$ Wu et al, Nature Genet 7491 (1994)

24 T R KIng et al Genomics 24159 (1994)

25 D M Scott et al Nature 376, 695 (1995)

26 A R Fattaey et al , Oncogene 83149 (1993)

27 S Tokuda, T Arrington E H Goldberg I Richey Nature 267, 433 (1977), M Shapro and E H Gold bert, J Immunogenet 11209 (1984)

28 J Ruppert et al, Cell 74929 (1993), $Y$ Chen et al $J$ Immunol 152, 2874 (1994). A Sette et al ibid $153,5586(1994)$

29 Supported by US Public Health Service grants Al20963 (to V HE) and Al33993 (to D FH), the J A Cohen Institute for Radiopathology and Radiation Protection $(E G)$ the Niels Stensen Foundation (E G ), and the Dutch Organization for Scientific Re search (NWO 901-09-201 to J M M d H)

14 July 1995 accepted 21 July 1995

\section{- TECHNICAL COMMENTS}

\section{Neutrophilia in Mice That Lack the Murine IL-8 Receptor Homolog}

G. Cacalano et al describe neutrophil and $B$ cell expansion in mice lacking the murine interleukın-8 receptor homolog (mIL-8Rh) (1). Neutrophils from these mice did not migrate toward ligands of the mIL-8Rh, and many fewer neutrophils arrived at sites of inflammation. These results could be expected, but the profound increase in the neutrophil and B cell populations was unexpected. Cacalano et al offer several possible explanations for this result, but strong evidence to support any one is lacking.

We would like to offer an alternatıve explanation, namely, that the neutrophil and $B$ cell expansion are compensatorv changes for poor resistance to normal flora and pathogen exposure. We base this argument on functional, histological, and clinical similarities between these mice and patients with leukocyte adhesion deficiency (LAD) Humans, dogs, and cattle can have LAD, and all afflicted individuals suffer a defect in the CD18 gene and lack expression of $\beta_{2}$ " integrin adhesion molecules on their neutrophils (2). Consequently, neutrophils are unable to adhere to and cross the endothelium, so they cannot reach sites of infection Indtviduals with LAD may appear generally normal, especially when bacterial exposure is minimized, but they often suffer chronic, subclinical infections. Classical signs of LAD include gingival infection with abnormal dentition, and among cattle, growth retardation $(3,4)$. Increased size of lymphoid organs and profound persistent neutrophilia with extensive granulopotetic activity outside of the bone marrow are hallmarks of this disease (5). Similarly, persistent neutrophilıa 